[RADIOCARBon, Vol 24, No. 2, 1982, P 171-181]

\title{
GLIWICE RADIOCARBON DATES VII
}

\author{
ANNA PAZDUR, ROMUALD AWSIUK, ANDRZEJ BLUSZCZ, \\ MIECZYSŁAW F PAZDUR, ADAM WALANUS, \\ and ANDRZEJ ZASTAWNY \\ Institute of Physics, Silesian Technical University \\ Krzywoustego 2, PL-44-100 Gliwice, Poland
}

The following list contains the measurements of archaeologic samples made during 1978 and 1979 using carbon-dioxide-filled proportional counters. Most of the samples were dated with counter No. 3 (L3) filled to 1 or 2 atm pressure (Mościcki and Zastawny, 1977). Our counter No. 1 (L1) previously described (Mościcki and Zastawny, 1976) has been remounted and is now operating at 2 atm pressure of carbon dioxide. Samples measured with this counter have date numbers starting with Gd-1000. Parameters of proportional counters are listed in Table 1. Our transistorized electronics is being gradually replaced by more compact integrated-circuit electronics in CAMAC system (Bluszcz and Walanus, 1980). Counts from proportional counter and guard counters are recorded in 5 channels and punched every 100 minutes. Typical measurement of any sample, including background and oxalic acid samples, consists of a series of 20 to 25 partial measurements. Partial results obtained in such series are analyzed on ODRA 1325 computer at the Computing Centre of the Silesian Technical University according to code C14C written in ALGOL (Pazdur and Walanus, 1979). Age calculations are based on contemporary value equal to 0.95 of the activity of NBS oxalic acid standard and on the Libby value for the half-life of radiocarbon. Ages are reported as conventional radiocarbon dates in years before AD 1950 . Corrections for isotopic fractionation in nature are made only for some samples with indicated values of $\delta^{13} \mathrm{C}$. Errors quoted $( \pm 1 \sigma)$ include estimated overall standard deviations of count rates of the unknown sample, contemporary standard, and background (Pazdur and Walanus, 1979).

Our earlier methods of sample pretreatment were described by Pazdur and Pazdur (1979) but in 1979 they were modified to ensure more complete removal of humic acid contaminants and now follow, to some extent, those described by Olsson (1979). Combustion and purification lines have been described by Pazdur et al (1979a). It is worthwhile to note that, in a series of experiments, a significant isotopic fractionation occurs during absorption of $\mathrm{CO}_{2}$ in $\mathrm{NH}_{4} \mathrm{OH}$ solution, amounting to $-3.41 \pm 0.8 \%$.

As part of our continuous efforts to achieve greater dating accuracy, a series of interlaboratory cross-check datings was made in 1978 and 1979. The results presented in Table 2 show no systematic difference between $\mathrm{Gd}$ dates and other dates. With the exception of our date, Gd-560, which must be suspect, all other dates agree with corresponding dates from other laboratories. 


\section{ACKNOWLEDGMENTS}

The authors are indebted to B J O'Brien from INS, DSIR, Lower Hutt, New Zealand, M A Geyh from Niedersachsisches Landesamt für Bodenforschung, Hannover, West Germany, W G Mook from Groningen, The Netherlands, and Andrzej Kanwiszer from Archaeologic and Ethnographic Museum Łódź, Poland, for their support of our cross-check dating project. Special thanks go to Stanisław Hałas and his coworkers from the Institute of Physics, Maria Curie Skłodowska University, Lublin, Poland for the ${ }^{13} \mathrm{C} /{ }^{12} \mathrm{C}$ determinations and to Helena Skorupka for her technical assistance in the laboratory.

\section{SAMPLE DESCRIPTIONS ARCHAEOLOGIC SAMPLES}

\section{A. Cuba}

Charcoal samples are from prehistoric Paleo-Indian sites in Cuba. All samples, except for Levisa and Rio Canimar, coll by Dept Archaeol, Acad Sci Cuba; subm Sept 1978 by Romuald Schild, Inst Hist Material Culture, Polish Acad Sci, Warsaw. For general bibliog of Funche culture, Seboruco-Mordan culture, and Canimar-Aguas Verdes cultures, see Kozłowski (1974). Sub-Taino culture is discussed by Tabio and Rey (1966).

Table 1

Parameters of proportional counters

\begin{tabular}{ccccc}
\hline & CO $_{2}$ pressure & B & $\mathbf{S}_{\mathrm{o}}=0.95 \mathrm{~A}_{\mathrm{ox}}$ & $\mathrm{F}=\mathrm{S}_{\mathrm{o}} / \sqrt{\mathrm{B}}$ \\
\cline { 3 - 4 } Counter & $\mathrm{atm}$ & Counts $/ \operatorname{minutc}$ & \\
\hline L1 & 2 & 9.4 & 37.8 & 12.3 \\
L3 & 1 & 3.1 & 10.3 & 5.9 \\
L3 & 2 & 3.4 & 20.6 & 11.2 \\
\hline
\end{tabular}

TABle 2

Results of interlaboratory cross-check samples

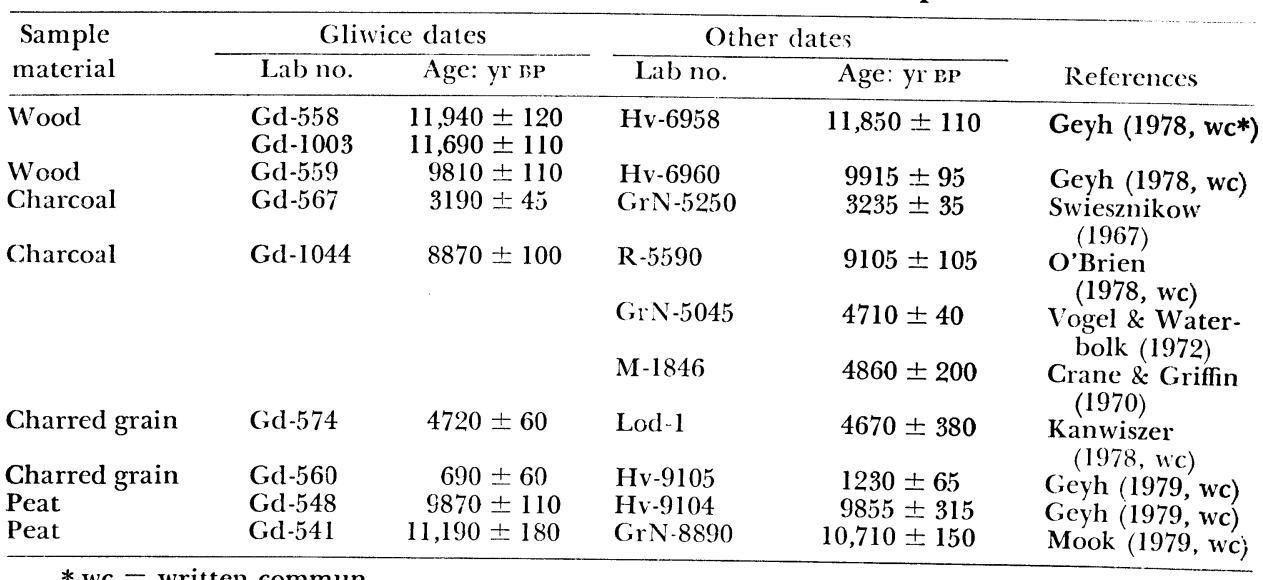


Funche culture

\section{Cueva de la Pintura series}

Samples from midden close to Cueva de la Pintura, Barrio La Furnia, Peninsula Guanahacabibes, Pinar del Rio $\left(21^{\circ} 55^{\prime} 28^{\prime \prime} \mathrm{N}, 84^{\circ} 02^{\prime} 48^{\prime \prime} \mathrm{W}\right)$, assoc with kitchen-midden refuse; some artifacts made of marine shell and stone; coll Jan 1973.

Gd-591. Cueva de la Pintura 1

$2930 \pm 80$

Unit U/E \#1, Block 1-I, Sec D, level 1.5 to $1.8 \mathrm{~m}$.

Gd-601. Cueva de la Pintura 2

$2800 \pm 60$

Unit U/E \# 1, Block 1-I, Sec D, level 1 to $1.25 \mathrm{~m}$.

Gd-1039. Cueva de la Pintura 3

$2160 \pm 60$

Unit U/E \# 1, Block 1-I, Sec A, level 0.5 to $0.75 \mathrm{~m}$.

Gd-613. Cueva de la Pintura 4

$2880 \pm 70$

Unit U/E \#2, Block 5, Sec D, level 1.5 to $1.75 \mathrm{~m}$.

Gd-1046. Cueva de la Pintura 5

$2840 \pm 60$

Unit U/E \#2, Block 5, Sec D, level 1.25 to $1.5 \mathrm{~m}$.

Gd-614. Cueva de la Pintura 6

$2720 \pm 70$

Unit U/E \#2, Block 5, Sec D, level 1 to $1.25 \mathrm{~m}$. Comment (MFP): dates agree fairly well with expected ages for Funche culture (Kozłowski, 1974, p 77-78).

\section{Perico I series}

From burial cave Perico I, Bahia Honda, Pinar del Rio $\left(22^{\circ} 52^{\prime} 42^{\prime \prime}\right.$ $\left.\mathrm{N}, 83^{\circ} 16^{\prime} 18^{\prime \prime} \mathrm{W}\right)$. Assoc material consists of kitchen-midden refuse with many human burials and a few artifacts made of marine shell and stone; coll March 1972. Dated to establish chronology of Funche culture. More detailed site inf is given by Pino and Alonso (1973).

Gd-616. Perico $\mathbf{I} / \mathbf{1}$

$1350 \pm 70$

From Trench 2, Sec 2, level 1.5 to $1.75 \mathrm{~m}$.

Gd-1051. Perico I/2

$1990 \pm 80$

From Trench 1, Sec 1, level 1.3 to $1.4 \mathrm{~m}$.

Gd-617. Perico I/3

$1500 \pm 60$

From Trench 1, Sec 1, level 1 to $1.2 \mathrm{~m}$.

Gd-618. Cueva de Isla 1

$910 \pm 90$

From midden in front of Cueva de Isla, Punta del Este, Isle of Pines $\left(21^{\circ} 37^{\prime} 36^{\prime \prime} \mathrm{N}, 82^{\circ} 32^{\prime} 58^{\prime \prime} \mathrm{W}\right)$, Block I, Sec A, level 0.5 to $0.75 \mathrm{~m}$, depth $0.57 \mathrm{~m}$. Assoc with a few artifacts of marine shell and stone, probably belonging to later phase of Funche culture. Coll March 1967. Comment: undersized, diluted. 
Gd-619. Los Pedregales 1

$1170 \pm 90$

From Cave \# 1 near Los Pedregales, Bauta, Prov Havana $\left(22^{\circ} 55^{\prime} 16^{\prime \prime}\right.$ $\mathrm{N}, 82^{\circ} 34^{\prime} 02^{\prime \prime} \mathrm{W}$ ), Trench \#2, Sec B, level 2 to $2.25 \mathrm{~m}$, depth $2.0 \mathrm{~m}$. Assoc with kitchen-midden refuse; a few artifacts of marine shell and stone, quite poor in manufacture. Coll July 1976.

Sub-Taino culture

Gd-1053. El Convento 1

$\mathbf{6 7 0} \pm 50$

From Site El Convento, Prov Cienfuegos (22 $01^{\prime} 25^{\prime \prime} \mathrm{N}, 80^{\circ} 22^{\prime} 06^{\prime \prime}$ $\mathrm{W}$ ), Pit \#2, level 0.25 to $0.5 \mathrm{~m}$, depth $0.45 \mathrm{~m}$. Assoc with much pottery; some artifacts of marine shell and stone; coll Nov 1974.

\section{Aguas Gordas series}

From Aguas Gordas, Rio Seco, Prov Holguin $\left(21^{\circ} 05^{\prime} 00^{\prime \prime} \mathrm{N}, 75^{\circ} 42^{\prime}\right.$ $01^{\prime \prime} \mathrm{W}$ ). Assoc cultural material was much pottery and artifacts of marine shell and stone; coll March 1971. Previous date from this site made in 1963 at Vernadsky Inst Geochem, Acad Sci USSR: MO-399, $1000 \pm 95$, (Nuria Gregori, 1978, written commun).

Gd-620. Aguas Gordas 1

$170 \pm 60$

From Midden \#2, Pit \# 1, level 0.5 to $0.75 \mathrm{~m}$.

Gd-1054. Aguas Gordas 2

$490 \pm 50$

Same loc, level 0.75 to $1 \mathrm{~m}$.

Gd-1055. Aguas Gordas 3

$580 \pm 60$

Same loc, level 1 to $1.25 \mathrm{~m}$.

Gd-621. Aguas Gordas 4

$710 \pm 70$

Same loc, level 1.25 to $1.5 \mathrm{~m}$.

\section{La Campana series}

From La Campana site, Banes, Prov Holguin $\left(20^{\circ} 58^{\prime} 00^{\prime \prime} \mathrm{N}, 75^{\circ} 42^{r}\right.$ $\left.58^{\prime \prime} \mathrm{W}\right)$. Assoc material was kitchen-midden refuse, much pottery, and artifacts of marine shell and stone; coll March 1972.

Gd-1056. La Campana 1

$600 \pm 60$

From Midden \#2, Block II, Sec D, level 1 to $1.5 \mathrm{~m}$.

Gd-624. La Campana 2

$510 \pm 40$

Same loc, level 0.75 to $1 \mathrm{~m}$.

Gd-1057. La Campana 3

From Midden \#2, Block I, Sec C, level 0.5 to $0.75 \mathrm{~m}$.

$490 \pm 45$

Seboruco-Mordan culture

\section{Levisa I series}

Charcoal and other carbonized organic substances from traces of hearths intercalated into clay and rubbish clay deposits, Site Levisa $1 / 1$, near Nicaro, Prov Oriente $\left(20^{\circ} 40^{\prime} \mathrm{N}, 75^{\circ} 30^{\prime} \mathrm{W}\right)$, in rock shelter ca $7 \mathrm{~m}$ 
above mean level of Levisa R. Coll and subm 1973 by J K Kozłowski, Inst Archaeol, Jagellonian Univ, Cracow. For other dates of SeborucoMordan culture, $c f$ Kozłowski (1974, p 67, Table X).

Gd-204. Levisa I/1, Layer V

$3460 \pm 160$

Gd-250. Levisa I/1, Layer VII

$5140 \pm 170$

Comment (JKK): agrees fairly well with archaeol estimate and other dates of Seboruco-Mordan culture.

Canimar-Aguas Verdes culture

Gd-203. Rio Canimar 17/VI

$1010 \pm 110$

Charcoal from traces of hearths in alluvial deposits on lower terrace of Rio Canimar R, near mouth in Gulf of Mexico, Prov Matanzas $\left(23^{\circ}\right.$ $01^{\prime} 49^{\prime \prime} \mathrm{N}, 81^{\circ} 29^{\prime} 38^{\prime \prime} \mathrm{W}$ ), depth 0.7 to $0.8 \mathrm{~m}$, ca $3 \mathrm{~m}$ asl. Coll and subm 1973 by J K Kozłowski. Comment (JKK): much younger than expected. According to classification of Kozłowski (1974), this site represents early formative period of Canimar-Aguas Verdes cultural complex.

\section{El-Tarif series}

$$
\text { B. Egypt }
$$

Charcoal from hearths in anthropogenic layer at El-Tarif, near Luxor, W bank of Nile $\mathrm{R}\left(32^{\circ} 30^{\prime} \mathrm{N}, 25^{\circ} 50^{\prime} \mathrm{E}\right)$, assoc with Nagadian finds, overlaying silty loam with Epipaleolithic finds, covered with anthropogenic rubble from Dynastic time (Ginter, Kozłowski, and Sliwa, 1979; Ginter, Kozłowski, and Drobniewicz, 1979). Coll 1978 and subm 1979 by Bolesław Ginter, Inst Archaeol, Jagellonian Univ, Cracow.

Gd-689. Tarif P1

$5070 \pm 60$

From depth ca $2 \mathrm{~m}$.

Gd-1127. Tarif P2

$4620 \pm 60$

From depth ca $1.8 \mathrm{~m}$.

General Comment (BG): good agreement with samples from other sites related to Nagadian culture dated to 4th millennium BC. Thermoluminescence dates from El-Tarif range from 4100 to $3600 \mathrm{BC}$ (Whittle, 1975).

\section{Quasr el-Saghe series}

Scattered charcoal from washed hearth in upper silty layer, from ancient deltaic deposits of Moeris Lake, Western Desert, $\mathrm{N}$ of Bisket Qarun Lake, SW of Quasr el-Saghe Temple $\left(30^{\circ} 40^{\prime} \mathrm{N}, 29^{\circ} 20^{\prime} \mathrm{E}\right)$. Layer of cross-bedded sand contains remains of Fayum A culture (Ginter et al, 1980). Coll and subm 1979 by Bolesław Ginter.

\section{Gd-709. QS I/79/1/PI}

$8840 \pm 890$

From depth 1.7 to $1.8 \mathrm{~m}$. Comment: undersized, diluted.

Gd-1140. QS I/79/1/P2

$5540 \pm 70$

From depth 1.7 to $1.75 \mathrm{~m}$. 
Gd-708. QS I/79/1/P3

$6040 \pm 650$

From depth ca $40 \mathrm{~cm}$. Comment: undersized, diluted.

Gd-693. QS V/79/P5

$5990 \pm 60$

From depth ca $10 \mathrm{~cm}$.

Gd-640. Ayorou 12/72

\section{Nigeria}

$830 \pm 60$

Charcoal from cultural layer at depth ca $3 \mathrm{~m}$ on left bank of Niger $\mathrm{R}$ $\left(14^{\circ} 55^{\prime} \mathrm{N}, 0^{\circ} 35^{\prime} \mathrm{E}\right), 20 \mathrm{~km} \mathrm{~N}$ of Ayorou, Nigeria, W Africa. Coll Dec 1972 and subm 1979 by Jerzy Lis, Inst Geol, Warsaw. Comment (JL): site probably belongs to Yatakala culture.

Bronze and Iron Ages

\section{Poland}

\section{Swibie series}

Charcoal from cemetery of mixed use, Site 16 , on culmination of parabolic dune $1.5 \mathrm{~km} \mathrm{~N}$ of Swibie, ca $25 \mathrm{~km} \mathrm{~N}$ of Gliwice $\left(51^{\circ} 31^{\prime} 43^{\prime \prime} \mathrm{N}\right.$, $18^{\circ} 31^{\prime} 47^{\prime \prime}$ E). Cemetery belongs to Upper Silesian - Little Poland group, Gliwice-Częstochowa subgroup of Lusatian culture (Kostrzewski, Chmielewski, and Jazdzewski, 1965, p 213-216; Gedl, 1959). Systematic excavations, conducted from 1961, yielded more than 350 burials with much pottery and bronze and iron artifacts (Wojciechowska, 1968; 1972; 1973; 1976; Wegrzykowa, 1964; 1969). Coll and subm 1977 and 1978 by Halina Wojciechowska, Gliwice Mus, Gliwice.

Gd-543. Swibie 321

$2590+60$

$\delta^{13} \mathrm{C}=-18.8 \%$

From fireplace in upper layer of skeletal burial, depth $40 \mathrm{~cm}$. Coll July 1977.

Gd-541. Swibie 325

$2250 \pm 60$

$\delta^{1.3} \mathrm{C}=-25.5 \%$

From fireplace in upper layer of skeletal burial No. 325, depth $63 \mathrm{~cm}$. Coll July 1977.

Gd-612. Swibie 355A

$2650 \pm 70$

From cremation burial No. 355, cinerary urn covered with remains of funeral pile, depth below $27 \mathrm{~cm}$. Coll Aug 1978 .

Gd-1045. Swibie 348

$\mathbf{7 3 0} \pm \mathbf{5 0}$

From fireplace in layer at depth 64 to $74 \mathrm{~cm}$, above skeletal burial No. 348. Comment (HW): assoc with Middle Age iron artifacts, sample dates later phase of occupation.

\section{Dobrzeń Mały series}

Charcoal from Site B of iron foundry settlement at Dobrzeń Mały near Opole $\left(50^{\circ} 45^{\prime} 00^{\prime \prime} \mathrm{N}, 17^{\circ} 52^{\prime} 45^{\prime \prime} \mathrm{E}\right)$. Coll June 1975 by Antoni Pawłowski; subm 1976 by Jerzy Rozpędowski, Inst Hist Architecture, Arts \& Tech, Wrocław Tech Univ, Wrocław. 
Gd-533. Dobrzeń Mały ob 690

From object No. 690, ar 211.

Gd-530. Dobrzeń Mały ob 720

From object No. 720, ar 191.

General Comment: other dates from this site: Object 19: Gd-263, $1770 \pm$ 140; Object 25: Gd-298, $1660 \pm 120$ (R, v 20, p 407); Object 685: Gd-488, $1720 \pm 70$; Object 722: Gd-489, $1760 \pm 70(\mathrm{R}, \mathrm{v} 22, \mathrm{p} 64)$.

\section{Rudki series}

Wood fragments from old mine "Staszic" in Rudki, NE part of Holy Cross Mts, N of Góra Chełmowa Mt $\left(50^{\circ} 54^{\prime} \mathrm{N}, 21^{\circ} 06^{\prime} \mathrm{E}\right)$, from layer IV at depth 16 to $18 \mathrm{~m}$. Systematic archaeol excavations of 1958 and 1959 resulted in discovery of large area of ancient dog headings. Coll Feb 1959 and subm 1977 by Kazimierz Bielenin, Archaeol Mus, Cracow.

\section{Gd-511. Rudki 1}

$1750 \pm 70$

Fragment of undecorticated round $\log$ (Pinus sp), $8 \mathrm{~cm}$ diam and $40 \mathrm{~cm}$ long, probably used as pit prop.

\section{Gd-512. Rudki 2}

Fragment of splintered beech wood, ca 2 to $3 \mathrm{~cm}$ thick and $22 \mathrm{~cm}$ long, probably fragment of shovel.

\section{Nowa Słupia series}

Charcoal (Abies alba and Pinus silvestris, id by Irena Gluza) from set of primitive iron-smelting furnaces, Site 11 at Nowa Słupia, ca $32 \mathrm{~km}$ $\mathrm{E}$ of Kielce $\left(50^{\circ} 52^{\prime} \mathrm{N}, 21^{\circ} 06^{\prime} \mathrm{E}\right)$. Site, on NE slope of Łysa Góra Mt, consists of 102 bloomery-type furnaces arranged in 2 series of 4 furnaces, type $2 \times 4$, according to Bielenin (1977). Coll Aug 1977 and subm by Kazimierz Bielenin.

Gd-507. Nowa Słupia, furn 63

$1800 \pm 100$ slag.

From depth ca $40 \mathrm{~cm}$, base of furnace No. 63, below large ferrugineous

Gd-508. Nowa Słupia, furn 87

$1930 \pm 100$ ous slag.

From depth ca $40 \mathrm{~cm}$, base of furnace No. 87 , below large ferrugine-

Gd-506. Nowa Słupia, furn 38/39

$1010 \pm 80$

From base of cupola holes of two destroyed furnaces, No. 38 and No. 39 , at depth ca $25 \mathrm{~cm}$.

Gd-505. Nowa Słupia, common

$$
1510 \pm 80
$$

From traces of several destroyed furnace holes, depth ca $25 \mathrm{~cm}$.

General Comment (KB): dates for furnaces No. 63 and 87 agree well with archaeol evidence and other radiocarbon dates from this region. Other 
two dates are considerably younger than expected; contamination with younger material is suspected.

\section{Historic period}

Gd-577. Władysławowo stem

Fragment of oak stem at depth ca $30 \mathrm{~cm}$ at base of Baltic sea near Władysławowo $\left(54^{\circ} 48^{\prime} \mathrm{N}, 18^{\circ} 25^{\prime} \mathrm{E}\right)$. Coll July 1978 by Wiesław Urbański; subm Sept 1978 by Maria Dyrkowa, Central Maritime Mus, Gdańsk. Dated typologically to 16 th century AD by Przemysław Smolarek.

\section{Tolkmicko series}

Timber from fragments of ship from meadow $3 \mathrm{~km}$ SW of Tolkmicko $\left(54^{\circ} 19^{\prime} \mathrm{N}, 19^{\circ} 32^{\prime} \mathrm{E}\right)$ on former ground of Vistula Bay, ca $2 \mathrm{~m}$ below sea level. Coll July 1979 by Zdzisław Kocur; subm Aug 1979 by Maria Dyrkowa. Samples dated typologically to Middle Ages by Jerzy Litwin.
Gd-1138. Tolkmicko rib
$190 \pm 45$
Gd-1139. Tolkmicko keel
$\mathbf{5 2 0} \pm \mathbf{5 0}$

\section{Gdańsk Shipwreck W-5 series}

Samples from wreck of ancient merchant ship W-5 (Smolarek, 1979) from depth $16 \mathrm{~m}$ at base of Gdańsk Bay, roadstead of Gdańsk harbor, ca $6.5 \mathrm{~km} \mathrm{NE}$ of estuary of Vistula $\mathrm{R}\left(54^{\circ} 28^{\prime} \mathrm{N}, 18^{\circ} 43^{\prime} \mathrm{E}\right)$. Wreck was raised Oct 1975. Samples were prepared and subm in 1977 and 1978 by Przemysław Smolarek. General inf about shipwreck is given by Smolarek (1979). Samples dated as part of complex interdisciplinary study of shipwreck, including its construction and classification (Litwin, 1977; 1979), analysis of wood from ship's hold (Heymanowski, 1979), and study of merchant marks found on barrels containing iron ore, tar, pitch, and potash (Sledź, 1979).

Gd-423. W-5:Frame No. 10

$580 \pm 140$

Oak wood, fragment of frame No. 10.

Gd-491. W-5:Tree nail A

$630 \pm 70$

Oak wood covered with tar. Tar removed by successive boiling in trichloroethylene.

Gd-500. W-5:Tree nail $B$

$670 \pm 60$

Independent run on 2nd part of same sample.

Gd-490. W-5:Animal hair A

$$
620 \pm 60
$$$$
\delta^{13} \mathrm{C}=-31.9 \%
$$

Caulking of animal hair, impregnated with tar and covered with sand and mud. Tar removed by successive boiling in trichloroethylene. Pretreatment: $1 \mathrm{~h}$ boiling in $1 \% \mathrm{HCl}$.

Gd-502. W-5:Animal hair B

$640 \pm 45$

Independent run on 2 nd part of same sample. 
Gd-501. W-5:Tar

High purity tar from one of undestroyed barrels belonging to cargo. Not pretreated.

Gd-499. W-5:Beeswax

$\mathbf{4 7 0} \pm \mathbf{4 5}$

$\delta^{13} \mathrm{C}=-34.8 \%$ o

Fragment of big blocks of pure beeswax from ship's cargo. Only mechanical cleaning of surface.

Gd-534. W-5:Clamping ring

$590 \pm 40$

Beech clamping ring from one of undestroyed barrels belonging to cargo.

Gd-535. W-5:Line

$590 \pm 40$

$\delta^{13} \mathrm{C}=-23.7 \%$

Pieces of partly charred line, covered with tar and mud, found in ship's hold. Tar removed by successive boiling in trichloroethylene.

Gd-590. W-5:Straw

$$
\begin{array}{r}
450 \pm 100 \\
\delta^{13} C=-26.6 \% \text { c }
\end{array}
$$

Pieces of unid. straw found in ship's hold. Comment: undersized, diluted.

General Comment (MFP): for detailed discussion of results of radiocarbon dating, see Pazdur et al (1979b). First five dates for frame, tree nails, and animal hair provide estimated date of launching; next five dates for materials belonging to ship's cargo provide estimate of date of sinking. Good agreement with historic dates suggested by Sledź (1979).

Gd-1010. Charzykowy boat

Fragment of outer part of boat made of single oak trunk ca $50 \mathrm{~cm}$ and $5.8 \mathrm{~m}$ long found at base of Charzykowy Lake ca $200 \mathrm{~m} \mathrm{~S}$ of Góra Zamkowa site $\left(53^{\circ} 47^{\prime} \mathrm{N}, 17^{\circ} 28^{\prime} \mathrm{E}\right)$ at depth $26 \mathrm{~m}$. Coll and subm May 1978 by Krzysztof Kruszelnicki, Underwater Archaeol Club, Warsaw.

\section{Góra Dobrzeszowska series}

Charcoal from Góra Dobrzeszowska site near Dobrzeszów village $\left(50^{\circ} 58^{\prime} \mathrm{N}, 20^{\circ} 15^{\prime} \mathrm{E}\right)$, ca $25 \mathrm{~km} \mathrm{NW}$ of Kielce. Coll April and subm June 1978 by Eligia Gassowska, Admin Board, Kielce.

\section{Gd-566. Góra Dobrzeszowska GD1}

$$
1170 \pm 35
$$

From burning layer in fill of culture wall made of loose stones, ar 08, Wall 1.

\section{Gd-1015. Góra Dobrzeszowska GD2}

$$
110 \pm 50
$$

From thick layer of charcoal and ash at $S$ altar, ar G11.

General Comment (EG): site expected to be from Roman period, 1st to 4 th century AD; dates much younger than expected. 


\section{Stołpie series}

Burned grains and wood from lowest wooden layer of construction at Stołpie village $\left(51^{\circ} 10^{\prime} \mathrm{N}, 23^{\circ} 21^{\prime} \mathrm{E}\right)$, ca $9 \mathrm{~km} \mathrm{NW}$ of Chełm. Samples taken from embankment made of wooden boxes filled with chalk rubble at depth 2.7 to $3 \mathrm{~m}$. Coll and subm 1978 and 1979 by Irena Kutyłowska, Dept Archaeol, Maria Curie Skłodowska Univ, Lublin. Botanical id of grains by Leszek Halicki and Władysław Kulpa, and burned wood by Agnieszka Kadej. For cultural stratigraphy, see Kutyłowska (1977); archaeol dating based on Early Medieval pottery indicates 11th to 13th century AD (cf Zaki, 1974, p 182-184); architectonic chronology 11th to 14th cent AD (Dalbor, 1959, p 179-192; Zaki, 1974, p 151-153).

\section{Gd-553. Stołpie 1}

Burned coniferous wood, E part of embankment.

Gd-554. Stołpie 2 locality.

Burned grains of Triticum compactum and Secale cereale, same

Gd-560. Stolpie 3

$690 \pm 60$

Burned grains of Pisum stativum and Vicia faba, same locality.

Gd-684. Stołpie 4

$1090 \pm \mathbf{5 0}$

Burned coniferous wood, W part of embankment.

Gd-1260. Stołpie 5

$\mathbf{1 0 0 0} \pm \mathbf{5 0}$ locality.

Burned grains of Triticum compactum and Secale cereale, same

\section{REFFRENCES}

Bielenin, Kazimierz, 1977, Frühgeschichtliches Bergbau- und Eisenhüttenwesen in Swietokrzyskie-Gebirge, in Piekarek, Udo and Saherwala, Geraldine, eds, Eisenverhüttung vor 2000 Jahren in der VR Polen: Berlin Staatliche Mus Preussischer Kulturbesitz, p 11-26.

Bluszcz, Andrzej and Walanus, Adam, 1980, Zestaw do amplitudowej i czasowej analizy impulsów z zespołów licznikowych súuzacych do pomiaru na:uralnych aḱtywności izotopu ${ }^{14} \mathrm{C}$ : Informatyczne systemy pomiarowe o skupionej i roz'ozonej inteligencji w systemie CAMAC, ZG SEP__ZZU J Polon_-IBJ, Warszawa, p 53-54.

Crane, H R and Griffin, J B, 1970, University of Michigan radiocarbon dates XIII: Radiocarbon, v 12, p 161-180.

Dalbor, W, 1959, Dwór ksiazçcy z X wieku na Ostrowie Lednickim: Slavia Antiqua, v 6 , p $172-288$.

Gedl, Marek, 1959, Zróznicowanie terytorialne kultury łuzyckiej na Górnym Slasku: Silesia Antiqua, v 1, p 11-29.

Ginter, Bolesław, Kozłowski, J K, and Drobniewicz, Barbara, 1979, Silexindustrien von El Tarif: Deutsches Archäol Inst, Abt Kairo, Archäol Veröffentlichungen, v 26, p $1-78$.

Ginter, Bolesław, Kozłowski, J K, and Sliwa, Joachim, 1979, Excavation report on the prehistoric and predynastic settlement in El-Tarif during 1978: Deutsches Archäol Inst, Abt Kairo Mitt, v 35, p 87-102.

Ginter, Bolesiaw et al, 1980, Excavations in the region of Quasr el-Sagha, 1979. Contributions to the Holocene geology, the Pre-Dynastic and Dynastic settlement in the Northern Fayum Desert: Deutsches Archäol Inst, Abt Kairo, Mitt, v 36, p $000-000$

Heymanowski, Kazimierz, 1979, Niektóre sortymenty drzewne w Polsce w XV w świetle materiałów z "miedziowca": Kwartalnik Historii Kultury Materialnej, v 27, p 345-351. 
Kostrzcwski, Józef, Chmielewski, Waldemar, and Jazdzewski, Konrad, 1965, Pradzieje Polski: Wrocław-Warszawa-Kraków, Ossolincum, 428 p.

Koz'owski, I K, 1974, Preceramic cultures in the Caribbcan: Uniwersytet Jagielloński, Zesz Nauk, v 386, Prace Archeol, No. 20, p 1-114.

Kutyłowska, Irena, 1977, Stołpie, gm Nowosió'ki: Informator Archeol, Badania 1976, p 235-236.

Litwin, Jerzy, 1977, Miedziowiec_interesujacy zabytek dawnej techniki okrętowej: Budownictwo Okretowe, No. 4, p 134-139. 1979, Studium konstrukcji i próba klasyfikacji "miedziowca": Kwartalnik Historii Kultury Materialnej, v 27, p 331-343.

Mościcki, W'odzimierz and Zastawny, Andrzej, 1976, Gliwice (Gdańsk) radiocarbon dates III: Radiocarbon, v 18, p 50-59.

1977. New proportional counter assembly in Gliwice ${ }^{14} \mathrm{C}$ Laboratory, in Povinec, $\mathrm{P}$ and Usacev, $\mathrm{S}$, eds, Low radioactivity measurements and applications: Internatl conf, The High Tatras, Proc, p 91-92.

Mościcki, Włodzimierz, Pazdur, Anna, Pazdur, Mieczysław, F, and Zastawny, Andrzej, 1978, Gliwice radiocarbon dates IV: Radiocarbon, v 20, p 405-415.

Olsson, Ingrid U, 1979, Radiometric dating, in Bcrglund, B E, ed, Palaeohydrological changes in the temperate zone in the last 15,000 years. Subproject B. Lake and mire environments, Project guide, v 2, Specific methods: Dept Quaternary Geol, Lund Univ, Lund, Sweden, p 1-38.

Pazdur, Anna, Pazdur, M F, and Zastawny, Andrzej, 1979, Gliwice radiocarbon dates V: Radiocarbon, v 21, p 165-170.

Pazdur, M F, Awsiuk, Romuald, Bluszcz, Andrzej, Hałas, Stanisław, Pazdur, Anna, Walanus, Adam, and Zastawny, Andrzej, 1979a, Preliminary results of the study of isotopic fractionation during chemical purification of carbon dioxide for radiocarbon dating: Radiochem Radioanal Letters, v 39, p 157-168.

Pazdur, M F and Pazdur, Anna, 1979, Methods of sample pretreatment in Gliwice Radiocarbon Laboratory: Muz Archeol i Etnog w Lodzi, Prace i Materiały, v 26, p 279-282.

Pazdur, M F, Pazdur, Anna, and Zastawny, Andrzej, 1980, Gliwice radiocarbon dates VI: Radiocarbon, v 22, p 61-67.

Pazdur, M F, Pazdur, Anna, Awsiuk, Romuald, and Walanus, Adam, 1979b, Daty wodowania i zatoniecia "miedziowca" uzyskane na podstawie analizy metoda ${ }^{14} \mathrm{C}$ : Kwartalnik Hist Kultury Materialnej, v 27, p 315-330.

Pazdur, M F and Walanus, Adam, 1979, Statistical analysis of data and age calculation in Gliwice Radiocarbon Laboratory: Muz Archeol i Etnog w Lodzi, Prace i Materiałyy, v 26, p 283-289.

Pino, M and Alonso, M, 1973, Excavaciones en la Cueva del Perico I: Ser Espeleologia, No. 45 .

Sinolarek, Przemysław, 1979, Badanie i wydobycie wraka "Miedziowca" (W-5): Kwartalnik Hist Kultury Materialnej, v 27, p 291-313.

Sledz, Edward, 1979, Merki kupieckie na towarach z "miedziowca": Kwartalnik Hist Kultury Materialnej, v 27, p 353-364.

Swiesnikow, I K, 1967, Kultura komarowska. Archeol Polski, v 12, p 39-107.

Tabio, E E and Rey, E, 1966, Prehistoria de Cuba: Acad Ciencias Cuba, La Habana.

Vogel, J C and Waterbolk, H T, 1972, Groningen radiocarbon dates X: Radiocarbon, v 14, p 6-110.

Wegrzykowa, Anna, 1964, Ogólne uwagi o wyrobach metalowych z cmentarzyska kultury łuzyckiej w Swibiu, powiat Gliwice: Zeszyty Gliwickic, v 2, p 133-148. 1969, Swibie, pow Gliwice: Silesia Antiqua, v 11, p 329-330.

Whittle, E H, 1975, Thermoluminescent dating of Egyptian predynastic pottery from Hamamieh and Qurna-Tarif: Archaeometry, v 17, p 119-129.

Wojciechowska, Halina, 1968, Wyniki badań archeologicznych prowadzonych w Swibiu, powiat Gliwice: Zeszyty Gliwickie, v 6, p 239-243.

1972, Badania wykopaliskowe w Swibiu w 1970 i 1971 roku: Zeszyty Gliwickie, v 9 , p 267-273.

1973, Wykopaliska w Swibiu powiat Gliwice w 1972 roku: Zeszyty Gliwickie, v 10, 243-246.

1976, Pradzieje ziemi gliwickiej: Zeszyty Gliwickie, v 12, p 7-30.

Zaki, A, 1974, Archeologia Małopolski Wczesnośredniowiecznej: Wrocław, Ossolineum, $654 \mathrm{p}$. 